\title{
РЕПРЕЗЕНТАЦІЯ ОБРАЗУ ГЕРОЯ-ВОЇНА В УКРАЇНСЬКІЙ СОЦРЕАЛІСТИЧНІЙ ЛІТЕРАТУРІ
}

\author{
УЛЯНА ФЕДОРІВ \\ Львівський національний університет імені Івана Франка, Львів - Україна \\ fedoriv_ulyana@yahoo.com; ORCID: 0000-0001-7295-3343
REPREZENTACJA OBRAZU BOHATERA WALKI W UKRAIŃSKIEJ LITERATURZE REALIZMU SOCJALISTYCZNEGO

\section{ULIANA FEDORIW}

Lwowski Uniwersytet Narodowy imienia Iwana Franki, Lwów — Ukraina

STRESZCZENIE. Przedstawiony artykuł proponuje analizę kanonu socrealistycznego w ukraińskich tekstach literackich, należących do autorów okresu sowieckiego, takich jak Natan Rybak, Jurij Zbanacki, Ołeś Honczar, Andrij Małyszko, Natalia Zabiła itd. Według licznych badań ów kanon jest traktowany jako ideologiczny projekt w zakresie kultury oraz literatury, którego zadaniem było formowanie odrąbnej tożsamości (homo sovieticus) oraz absolutyzacja władzy sowieckiej na różnych poziomach życia, zarówno państwowego, jak i prywatnego. W tekstach kultury kanon socrealizmu był powołany do stworzenia monostylistycznego systemu ze ścisłymi regułami, rozpisanymi schematami, specjalnie przewidzianymi typami bohaterów. Socrealistyczny kanon narzucał kulturze i sztuce schematy analizy i odzwierciedlenia nie prawdziwej, lecz wyimaginowanej rzeczywistości. Już od lat 30. XX wieku literatura reprezentuje liczne teksty odpowiadające regułom stylu ideologicznego. Wówczas literatura zostaje przekształcona w produkt kultury masowej, mający typową strukturę przewidywalności i uznawalności. Celem takiego eksperymentu nad literaturą piękną było zarówno przekształcenie kultur narodów podbitych przez ZSRR, jak i zmiana sposobu odbioru rzeczywistości. Estetyzacja i fałszowanie sowieckiego trybu życia, powszechna dominacja pierwiastków ideologicznego oraz totalitarnego w zakresie kultury, formowanie socrealistycznej teorii jako procesu polityzacji świadomości artystycznej — to czynniki decydujące o rozwoju i funkcjonowaniu kanonu literatury ukraińskiej okresu sowieckiego. Autorka artykułu proponuje nowe ujęcie literackiej reprezentacji sowieckiego panteonu bohaterów w tekstach socrealistycznych. System sowiecki, budując utopię o nastaniu „,́́wietlanej przyszłości”, potrzebował „nowego człowieka”, na kształtowanie którego były skierowane wszelkie starania. A zatem główną uwagę w danym badaniu skupiono na roli obrazu 
bohatera walki w socrealistycznym tekście. Obraz ów na skutek propagandy i agitacji zapisał się na długi czas w świadomości zbiorowej.

Słowa kluczowe: socrealizm, kanon socrealistyczny, ideologia, bohater walki, „nowy człowiek”.

\title{
REPRESENTATION OF THE HERO-WARRIOR'S IMAGE IN UKRAINIAN SOCIALIST REALISM LITERATURE
}

\author{
ULIANA FEDORIV \\ Ivan Franko National University of Lviv, Lviv — Ukraine
}

\begin{abstract}
ABSRACT. The article is devoted to the research of socialist realism canon in Ukrainian literature. This canon is considered an artificially modeled power project in the sphere of culture and literature which aimed at creating a monostylistic system with clearly defined rules and recommended schemes, especially including thought-out characters understandable for the mass Soviet reader in order to monopolize power at all levels and to establish a new Soviet identity ("homo sovieticus"). The socialist realism canon is a complex and heterogeneous phenomenon. It imposed patterns for analysing and reflecting on reality in art and culture. From the 1930s, any texts following the authorities' regulations acquired a typical structure, predictable and recognizable features that turned literature into a mass-produced uniform "artistic" product. The task of such a governmental experiment was both to transform the world, and to change the way reality was perceived. The aesthetized falsification of existence, the clear domination of everything "ideological" and "totalitarian" in the field of culture, shaping the socialist realistic theory as a process of politicizing artistic consciousness - these are the blocks that determined the formation and functioning of the socialist realism canon of Ukrainian literature. The publication reflects a new vision of the problem of the literary representation of the Soviet Pantheon of Heroes in the socialist realism texts, in particular novels by Natan Rybak, Yurii Zbanatskyi, Oles Honchar, Andrii Malyshko, Natalia Zabila etc. Basically, the idea is that in order to build a bright future the Soviet system needed a new man, so all the forces were thrown into the "new anthropological type". The article deals with the modeling role of the hero-warrior in the socialist realism text. This image was established in the mass consciousness by means of propaganda and agitation.
\end{abstract}

Keywords: socialist realism, socialist realism canon, ideology, hero-warrior, "new man”.

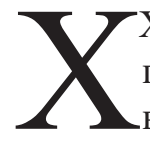

ХІ століття вимагає від сучасного літературознавства ревізії багатьох пластів української культури, що ігнорувалися роками. До категорії відкинутих та забутих довгий час належала і проблема соцреалістичного канону. На сьогодні орієнтири змінено. Про це свідчить вихід у світ цілого ряду літературознавчих, культурологічних, соціологічних, антропологічних досліджень про радянське [Борев 2008; Захарчук 2008; Кларк 2002; Лебедева 2012; Советское багатство 2002; Соцреалистический канон 2000; Хархун 2009; Socrealizm 2006; Studia Sovietica 2010; Studia Sovietica 2011; Studia Sovietica 2014]. Це, звичайно, викликане суспільно-політичними змінами, які 
передбачають процес модифікації попереднього типу культури, що був міцно пов'язаний із соцреалізмом, без дослідження якого неможливо дати цілісну характеристику українській літературі XX століття. Потреба перепрочитання та переосмислення соцреалістичної літератури - одне із ключових завдань актуального наукового вивчення в сучасному літературознавстві. За активного дослідження цієї теми надалі залишаються цілі прогалини “незайманих" соцреалістичних проблем, серед яких і проблема типології пантеону радянських героїв, які узагальнювали образ нової радянської людини, творця щасливого радянського майбутнього: „Нові герої радянської літератури - пролетарські революціонери, рядові працівники, будівники соціалістичного будівництва, творці і воїни, виховані комуністичною партією, по суті являють собою новий тип суспільної людини. У своїй праці і боротьбі вони натхненні ідеєю любові до трудящих людства, пройняті духом колективізму і $є$ найяскравішими виразниками соціалістичного гуманізму" [Історія української літератури 1957: 16].

Апологети радянської системи свідомо використали літературу як владний механізм, вбачаючи у ній не ціль, а лише засіб ідеологічного впливу. Так, Анатолій Луначарський зазначив, що потрібно „оволодіти «душею» людини на практиці”, ,абсолютно свідомо й абсолютно точно впливати на цю саму внутрішню людину так, щоб іiі поведінка і свідомість змінювалися в тому напрямі, який ми (комуністи) собі ставимо за мету" [Луначарский 1931: 29-30].

Для здійснення такої мети у 1932 році було видано постанову ЦК ВКП(б) Про перебудову літературно-художніх організаиій [Про перебудову літературно-художніх організацій 1932], тим самим влада ініціювала здійснення своєї тези про “перековування людського матеріалу”, директивно узаконену на Першому всесоюзному з'їзді радянських письменників у 1934 році.

Людині в такий спосіб нав'язували уніфіковані мислення, переконання, спосіб життя, вчинки. Ідеологема нової людини виникла як версія суб'єкта докорінних змін, виконавця плану побудови комунізму. Радянській людині приписували виняткові здібності та уміння, високий моральний, суспільний та колективний дух, підпорядкований думці про те, що влада повинна турбуватися про народ, а він зобов'язаний підтримувати владу.

Основними рисами нової людини стають самопожертва, героїзм, трудовий дух, колективізм в ім’я радянської держави: „Позитивний герой - «нова людина» - наділявся соціально цінними якостями, такими як трудовий та бойовий героїзм, відсутність жадібності та приватновласницьких пристрастей, колективізм, допомога слабшим" [Борев 2008: 176]. Процес створення нової людини із впевненістю можна порівняти з лабораторією психогенної інженеpiї, яка допомагає реалізувати проект владного контролю над особистістю. Радянська система формувала нову людину шляхом заперечення усталених духовних цінностей народу, використовуючи методи соціального інжинірингу, що допомагав владі міняти не лише ідеали, але й поведінку людей. Нова 
радянська людина мала бути відданою цілям партії, а маніпуляція масовою свідомістю здійснювалася відповідно до офіційної ідеології за допомогою державних інститутів та засобів тотальної пропаганди. Відповідно до партійних вимог саме застосування маніпулятивної стратегії та процес імперативного впливу, що здійснювала партія, дали можливість виховати нових людей як патріотично налаштовану масу, яка готова на самопожертви, трудові подвиги та самозречення. Саме таких героїв влада підносила та міфологізувала: Коли народ до власних рук / узяв життя й свободу, / для зльоту творчості й наук / не стало перешкоди. / Країна крила розп'яла, / синів своїх призвала / і почала такі діла, / щзо в казках лиш бували [Забіла 1986: 55].

Чимало дослідників соцреалізму вказують на реалізацію колективної міфотворчості в радянських текстах: „Основна мета - створення міфу про радянську людину як людину нової людської формації - зачіпала усі сфери можливого впливу на світогляд індивіда" [Лебедева 2012: 292]. При цьому в тоталітарному суспільстві формою політичного міфу виступає ідеологія, яку Поль Рікер називає одним із варіантів "спотвореного ставлення до реальності”, акцентуючи увагу на тому, що „це, зрештою, система ідей, що абсолютизуються внаслідок неможливості їхнього співвіднесення з реальністю” [Рікер 2005: 378].

Основною метою тоталітарного керівництва було так виховати радянську людину, щоб вона відчувала внутрішню потребу повної самовіддачі державі, щоб це стало її внутрішньою метою: „Радянське мистецтво стверджує, що радянська людина повинна віддавати себе людям, бути людиною для інших, інакше егоїстична замкненість позбавляє ії життя сенсу, перетворюючи його в абсурд" [Личность в ХХ столетии 1979: 216]. Як ідеал утверджується ідеологізований носій усіх найкращих людських якостей, покликаний творити комунізм — „царство нової людини” [Лахузен 1992: 202]. Ця радянська людина функціонувала виключно як біографічний проект влади, тому всі найкращі якості були регульовані і спрямовані лише на реалізацію партійного проекту побудови світлого майбутнього.

Зогляду на те, що мілітарна стратегія стала вирішальною в суспільних відносинах СРСР, стає зрозумілим, що першочергово пантеон героїв почали поповнювати герої-воїни в різних іпостасях — герой авіації, герой-танкіст, герой-партизан, герой-генерал тощо. До цього блоку соцреалістичних текстів можемо зарахувати Земля гуде, Прапороносиі Олеся Гончара, Вони не прийшли Юрія Смолича, Таємниця Соколиного бору та Лісова красуня Юрія Збанацького, Сашко Леоніда Смілянського, Мічніші за сталь Вадима Собка, Останній день лікаря Онипки Натана Рибака, Фронт Олександра Корнійчука, Патріот Петра Панча тощо.

Мілітаризація була способом розбудови великої держави, бо саме мілітарну складову використовують задля формування та утвердження колек- 
тивної ідентичності в рамках радянського міфотворення. Війні приписували ознаки сакральності, жертовності, героїчності. Армії надали особливого статусу в соціальних відносинах з державою, закріпивши за військовими статус охоронців, рятівників, визволителів. Усіх героїв-воїнів наділяли рисами напівбогів, які здатні через війну пере-сотворитися і пере-сотворити світ: саме завдяки їм держава проходить усі випробування та готова до побудови нового майбутнього: „У системі координат совєтської та нацистської моделі тоталітаризму вирізняється установка на тотальну мілітаризацію свідомості. Мілітаризм стає організуючим принципом ідеології та культури, породжує комплекс міфів, які в різних модифікаціях фігурують протягом XX століття. Мілітарна культура закріплює за насильством і агресією функції пересотворення старого та будівництва нового світу" [Захарчук 2008: 54]. Успішне вирішення суспільних проблем невіддільно пов'язане з військовою доктриною, а мілітарні норми поширюються на повсякденне життя та визначають його пріоритети. Гасло „перемога будь-якою ціною” сприймалося як безапеляційно правильне. Завдання героя-воїна - виконати наказ вищого керівництва заради перемоги. Отож масовий героїзм, самовідданість та самопожертва, компетентність та відвага стали визначальними рисами героїв-воїнів, а їх репрезентація стає обов'язковою у соцреалістичних текстах.

Важливим елементом біографії радянського героя-воїна $є$ смерть, що може реалізуватись чи через ритуальне жертвоприношення, чи через смерть для історії, чи через тілесну смерть заради духовного переродження нащадків. При цьому цінність окремого людського життя зводиться до нуля, бо основне - це виконати завдання партії, захистити державу, сприяти здійсненню плану побудови нової держави та народження нової людини. Життя однієї людини не має ваги, бо „смерть героя - чиста рефлексія більш суттєвої форми. Цей факт підтверджує високий ступінь деперсоналізації героя. Не важливо, чи живе він після смерті чи ні, індивідуальна трагедія не $є$ історичною" [Кларк 2002: 158]. Перемога над ворогом кодифікувалася не як особиста заслуга, а як торжество цілого народу, тріумф радянської системи. Війну означували як “визвольну”, “священну”, сакралізуючи визвольну місію радянської армії та іiі воїнів-героїв. Тому характерною рисою соцреалістичнихтекстів $є$ колективний героїзм та монументалізм. Радянський герой-воїн може досягнути мети лише у взаємозв'язку із системою, із іншими героями, адже ідентифікація через “ми” домінувала в соцреалістичних текстах: - ...Mи - молоді громадяни Радянського Союзу. Нам безмежно рідна нама Вітчизна, ми теж повинні боротись за ї̈ честь і волю. і ми вже боремось. Ми можемо сказати Червоній Армії, що ми теж воїни ... / _ ...Нас ніколи не забуде Вітчизна. Вона врятує нас із страшної неволі! [Збанацький 1985: 97].

Радянська влада 3 30-х років засобами пропаганди втілювала ідеологічну стратегію підготовки до війни, готовності до мобілізації, тому гордість 
і честь умерти за країну закарбовувалися в головах мільйонів радянських людей. Війну почали трактувати як можливість переродження, як завершальний етап боротьби зі старим світом, із темним минулим, як старт у процесі творення світлого радянського майбутнього: „Домінація мілітарного чинника у вирішальних суспільних перетвореннях дає підстави вести мову про його особливу роль у тоталітарному досвіді та спонукає до висвітлення його дії у громадсько-політичному та культурно-антропологічному аспектах. Можна стверджувати, що мілітаризація свідомості як перенесення форм і методів воєнної організації у сферу цивільних відносин формує найпотужніші суспільні міфи, визначає засадничі архетипи літератури і стандарти культурного спілкування" [Захарчук 2008: 4].

Особливу увагу було зосереджено на зображенні дитинства та “перековці" дитини в героя-воїна. Діти та підлітки — це нові герої радянських творів, що $€$ носіями цінностей, вмотивованих ідеологічними постулатами в ім'я вищого ідеалу - комунізму. Вони рано дорослішають, готові йти на війну, щиро відчувають відповідальність перед суспільством, беруть активну участь у суспільному житті, ризикують життям: Ось $і$ зустрілись вони віч-навіч. Старий вовк, досвідчений убивия, капіталіст Вільгельм-Фрідріх-Отто фон Фрейліх і украйнський юнак, комсомолещь Михайло Мирончук. / Мишко не злякався $і$ не здригнувся, побачивши наближення генерала. Він знав - за ним майбутнє, за ним нове життя. Це йому по-весняному яскраво світить сонце. А фон Фрейліх похолов, наче відчув за плечима смерть [Збанацький 1985: 313]. Нові радянські герої-воїни не відчувають болю, не вміють сумніватися, чітко виконують доручення, наче роботи-трансформери, які здатні довести до кінця будь-яке завдання заради того, щоб стати новою людиною, для якої безстрашність та тотальна солідарність $€$ домінантними рисами. Так народжувались “сини полків" та “гвардії Савочки”: $i$ Федько свого дочекався. Якось на шостий чи сьомий день важкий ширококостий літак з'явився якраз над Федьковою сосною. Дуло кулемета швидко начілилося прямісінько йому в голову. / Разів зо три диркнув кулемет. Літак схитнувся, зачмихав димом, блиснуло під крилом рухливе полум'я. За мить літак зник сперед очей, а ще за хвилину почувся важкий удар об землю і страхітливий вибух [Збанацький 1968: 40].

Беззаперечною рисою героя-воїна $є$ його готовність до жертовності заради партії та держави. Апелюючи до Жана Бодріяра [Бодріяр 2004], жертовність можемо тлумачити як перетворення реальності відповідно до вимог соціальної групи чи груп, а смерть у такому випадку набуває ознак такої, що регламентується владою. Смерть $є$ важливим елементом становлення героя, тому в текстах часто описані картини ритуального жертвопринесення, пропагується культ героїзму та смерть задля держави (тілесна смерть дає духовне переродження в пам'яті нащадків, що втілено у формулі “живіший за всіх 
живих"), персонажам приписується героїчний код канонізації. Так, в оповіданні Натана Рибака Прапор бачимо чітко прописану схему ритуалізованої смерті героя та його увічнення: замучений, повішений нацистами радянський солдат уночі “воскресає”, йде вулицями Києва, милується своїм рідним містом, бачить його велич та красу [Рибак 1949]. Тема безсмертя радянських героїв втілена в цьому образі дуже глибоко та хвилююче. Валентина Хархун таку модель описує як модель “обміну”: людина отримує безсмертя і вічну славу героя в обмін на фізичну смерть, яку держава замовила чи на яку дала згоду [Хархун 2009: 272-273]. Показовим у даному контексті є уривок $з$ поеми Прометей Андрія Малишка, де автор порівнює молодого радянського розвідника з Прометеєм, який свідомо обрав смерть, щоб не наражати на небезпеку інших. Поет змальовує картину страти бійця: його спалюють, але він упевнений, що відродиться, наче фенікс із попелу в наступних поколіннях, тому автор уводить у текст образ хлопчини, який підбирає спопелілі кістки розвідника: - Дивіться, люди, по мені / Устануть інші в пломені, / Ставайте й ви в трудні походи. / Не вип 'ють прокляті заброди / Живущу кров мою. О нi! [Малишко 1976: 179].

Цей приклад дає підстави говорити про міфологізацію тоталітарного буття, де герой виступає як будівничий нового життя, як символічний переможець, що долає усі перешкоди та усіх ворогів, але який часто мусить пройти ритуал символічної смерті. Таке помирання і наступне відродження $\epsilon$ обов'язковим компонентом традиційних ритуалів переходу з одного (гіршого) світу в інший (кращий): „У традиційному ритуалі переходу підготовка до ініціації зазвичай визначається як фаза «зміни» чи «лімінації», оскільки включає символічне повернення до хаосу. Щоб стати новим, старе спочатку повинно бути аннігільоване" [Кларк 2002: 154]. Однак у літературі соцреалізму “символічною” стає смерть фізична, тоді як вічне життя героя-воїна забезпечує йому пам'ять народу в піснях чи віршах, у званні „Героя СРСР”, увіковічення у формі гранітних пам'ятників воїнам-визволителям, в образі вічного вогню тощо (тут маємо справу з типовими фетишами радянського суспільства). Погоджуючись із думкою Катеріни Кларк про смерть героя як чисту рефлексію, можна стверджувати про високий ступінь деперсоналізації героя, індивідуальна трагедія якого не має суспільного-історичного значення.

Аналізуючи героя-воїна як новий тип позитивного героя соцреалістичних текстів, варто вказати на його категоріальну різноманітність. Це партизани, генерали, танкісти, моряки тощо. Проте всі вказані типи героїв $є$ голосами радянської влади, іiі рупором; їхнє завдання — реалізувати тоталітарний проект радянського воїна-богатиря, якому підвладні усі стихії, який здатен виконувати роль символічного супергероя, який вписуватиметься в офіційну версію пам'яті про війну, тим самим підтримуючи мілітарну стратегію ра- 
дянської влади як культурну доктрину. Саме в цьому контексті чітко простежується активне використання мілітарної свідомості як способу утвердження колективної ідентичності у процесі політичного міфотворення. Культивування такого типу героїв мало подвійну функцію - утвердження міфу про колективну загрозу, а відтак і виняткову місію радянського воїна, а також розгортання офіційної версії “історичної правди” та спотворення історичної пам'яті. У низці творів радянські герої-воїни, окрім оборони власної держави, власного простору, виконували й інші накази влади - захист та розвиток “братніх” територій. Таке підкорення може здійснюватися за допомогою двох механізмів: поширенням ідеології соціалізму на зовнішніх теренах та культу соціалістичної праці на внутрішній території. Так, виникають твори про радянських визволителів Свропи (наприклад, у романі-трилогії Прапороносиі Олеся Гончара [Гончар 1975] простежується замаскована лінія поширення комуністичної ідеології в Свропі) та виробничі романи, темою яких була індустріалізація країни.

Підсумовуючи, можемо вказати на безапеляційність героїзації радянського простору війни в літературі соцреалізму. Усі складові організації художнього тексту прямо залежали від основної ідеї - утвердження мілітарної стратегії в рамках соцреалізму, а героєві-воїну, захиснику, визволителю відводились чільні позиції в розбудові героїчного пантеону радянської літератури. Радянська влада свідомо вибудовувала міф величі та непереможності радянської армії, нарощуючи мілітарні потуги і на рівні “художнього арсеналу”, і на рівні військово-технічного арсеналу, тим самим визначаючи пріоритети в житті нової радянської людини.

\section{Список використаної літератури}

Бодріяр Ж., Символічний обмін і смерть, Львів: Кальварія, 2004.

Борев Ю., Соииалистический реализм: взгляд современника и современный взгляд, Москва: АСТ, 2008.

Захарчук I., Війна і слово: мілітарна парадигма літератури соиіалістичного реалізму, Луцьк: Твердиня, 2008.

Iсторія української літератури: у 2 т. Київ: Вид-во АН УРСР, 1957, т. 2, Радянська література.

Кларк К., Советский роман: история как ритуал, Екатеринбург: Изд-во Уральского унта, 2002.

Лахузен Т., Новый человек, новая женщина и позитивный герой, или К семиотике пола в литературесочиалистического реализма, [в:] Вопросы литературы, 1992, № 1, с. 184-205.

Лебедева Е.Г., Советская культура: идеология и мифология, [в:] Труды Русской антропологической школы, Москва: РГГУ, 2012, вып. 11, с. 283-292.

Личность в ХХ столетии: анализ буржуазных теорий, отв. ред. М. Б. Митин, Москва: Мысль, 1979. 
Луначарский А.В., Искусство как вид человеческого поведения, Москва-Ленингравд: Гос. мед. изд-во, 1931.

Про перебудову літературно-художніх організацій: постанова Політбюро ЦК ВКП (б) від 23 квітня 1932 р., [в:] Електронний ресурс: http://www.hist.msu.ru/ER/Etext/ USSR/1932.htm (13.10.2014).

Рікер П., Ідеологія та утопія, Київ: Дух і літера, 2005.

Советское багатство: статьи о культуре, литературе и кино, ред. М. Р. Балина, Санкт-Петербург: Академический проект, 2002.

Сочреалистический канон, под общ. ред. Х. Гюнтера, Е. Добренко, Санкт-Петербург: Академический проек, 2000.

Хархун В., Сочреалістичний канон в украӥнській літературі: генеза, розвиток, модифікації, Ніжин: ТОВ „Гідромакс”, 2009.

Socrealizm: fabuły — komunikaty — ikony, red. Krzysztof Stępnik, Magdalena Piechota, Lublin: Wyd-wo Uniwersytetu Marii Curie-Skłodowskiej, 2006.

Studia Sovietica: збірник, відп. ред. В. П. Хархун, Київ: Ін-т літ-ри ім. Т. Г. Шевченка НАН України, 2010, вип. 1:Ідеологічні та естетичні стратегії соцреалізму.

Studia Sovietica: збірник, відп. ред. В. П. Хархун, Київ: Ін-т літ-ри ім. Т. Г. Шевченка НАН України, Ніжин: Видавець ПП Лисенко М. М., 2011, вип. 2: Семіосфера радянської культури: знаки і значення.

Studia Sovietica: збірник, відп. ред. В. П. Хархун, Київ: Ін-т літ-ри ім. Т. Г. Шевченка НАН України, Ніжин: Видавець ПП Лисенко М. М., 2014, вип. 3: Хронологія радянської культури: константи й трансформації.

\section{Список використаних джерел}

Гончар О., Прапороносиі, Київ: Дніпро, 1975.

Забіла Н., Наша Батьківщина, Київ: Веселка, 1986.

Збанацький Ю., Гвардії Савочка, Київ: Веселка, 1968.

Збанацький Ю., Таємниця Соколиного бору, Київ: Веселка, 1985.

Малишко А., Прометей: вибрані твори, Київ: Веселка, 1976.

Рибак Н., Прапор, [в:] Н. Рибак, Оповідання, Київ: Радянський письменник, 1949.

\section{Spysok vykorystanoi literatury [References]}

Bodriiar Zh., Symvolichnyi obmin i smert [A Symbolic Exchange and Death], Lviv: Kalvariia, 2004. Borev Yu., Sotsialisticheskij realizm: vzglyad sovremennika i sovremennyj vzglyad [Socialistic Realism: a Modern Man's Opinion and the Modern Opinion], Moskva: AST, 2008.

Zakharchuk I., Viina i slovo: militarna paradyhma literatury sotsialistychnoho realizmu [A War and a Word: a Military Paradigm in Literature of Socialist Realism Time], Lutsk: Tverdynia, 2008 . 
Istoriia ukrainskoi literatury [The History of Ukrainian Literature]: u 2 t. Kyiv: Vyd-vo AN URSR, 1957, t. 2, Radianska literatura.

Klark K., Sovetskij roman: istoriya kak ritual [The Soviet Novel: History as a Rite], Ekaterinburg: Izd-vo Uralskogo un-ta, 2002.

Lakhuzen T., Novyj chelovek, novaya zhenshhina i pozitivnyj geroj, ili K semiotike pola $v$ literaturesotsialisticheskogo realizma [A New Man, a New Woman and a Positive Hero or Towards Gender Semiotics in Literature of Socialist Realism Time], [v:] Voprosy literatury. 1992, № 1, s 184-205.

Lebedeva E.G., Sovetskaya kultura: ideologiya i mifologiya [Soviet Culture: Ideology and Mythology], [v:] Trudy Russkoj antropologicheskoj shkoly, Moskva: RGGU, 2012, vyp. 11, s. 283-292.

Lichnost v XX stoletii: analiz burzhuaznykh teorij [A Personality of the XX Century: a Research on Bourgeois Theories], otv. red. M. B. Mitin, Moskva: Mysl, 1979.

Lunacharskij A.V., Iskusstvo kak vid chelovecheskogo povedeniya [Art as an Expression of Human Behaviour], Moskva-Leningravd: Gos. med. izd-vo, 1931.

Pro perebudovu literaturno-khudozhnikh orhanizatsii [About a Redevelopment of Literature and Artistic Institutions]: postanova Politbiuro TsK VKP (b) vid 23 kvitnia 1932 r., [v:]

Elektronnyi resurs: http://www.hist.msu.ru/ER/Etext/USSR/1932.htm (13.10.2014).

Riker P., Ideolohiia ta utopiia [Ideology and Utopia], Kyiv: Dukh i litera, 2005.

Sovetskoe bagatstvo: stati o kulture, literature i kino [Soviet Cornucopia: Articles about Culture, Literature and Cinema], red. M. R. Balina, Sankt-Peterbur: Akademicheskij proekt, 2002. Sotsrealisticheskij kanon [A Canon of Socialistic Realism], pod obshh, red. Kh. Gyuntera, E. Dobrenko, Sankt-Peterburg: Akademicheskij proek, 2000.

Kharkhun V., Sotsrealistychnyi kanon v ukrainskii literaturi: heneza, rozvytok, modyfikatsii [A Socrealistic Canon in Ukrainian Literature: Beginning, Development, Modifications], Nizhyn: TOV „Hidromaks”, 2009.

Socrealizm: fabuly - komunikaty - ikony [Socialistic Realism: Plots — Messages — Icons], red. Krzysztof Stępnik, Magdalena Piechota, Lublin: Wyd-wo Uniwersytetu Marii CurieSkłodowskiej, 2006.

Studia Sovietica: zbirnyk, vidp. red. V. P. Kharkhun, Kyiv: In-t lit-ry im. T. H. Shevchenka NAN Ukrainy, 2010, vyp. 1: Ideolohichni ta estetychni stratehii sotsrealizmu.

Studia Sovietica: zbirnyk, vidp. red. V. P. Kharkhun, Kyiv: In-t lit-ry im. T. H. Shevchenka NAN Ukrainy, Nizhyn: Vydavets PP Lysenko M. M., 2011, vyp. 2: Semiosfera radianskoi kultury: znaky i znachennia.

Studia Sovietica: zbirnyk, vidp. red. V. P. Kharkhun, Kyiv: In-t lit-ry im. T. H. Shevchenka NAN Ukrainy, Nizhyn: Vydavets PP Lysenko M. M., 2014, vyp. 3: Khronolohiia radianskoi kultury: konstanty y transformatsii.

\section{Spysok vykorystanykh dzherel [References]}

Honchar O., Praporonostsi [Standard-bearers], Kyiv: Dnipro, 1975. 
Zabila N., Nasha Batkivshchyna [Our Homeland], Kyiv: Veselka, 1986.

Zbanatskyi Yu., Hvardii Savochka [Savochka Guards], Kyiv: Veselka, 1968.

Zbanatskyi Yu., Taiemnytsia Sokolynoho boru [The Secret of the Falcon Forest], Kyiv: Veselka, 1985.

Malyshko A., Prometei: vybrani tvory [Prometheus: Selected Works], Kyiv: Veselka, 1976.

Rybak N., Prapor [Flag], [v:] Rybak N., Opovidannia, Kyiv: Radianskyi pysmennyk, 1949. 